Лейсан Халитова,

Виктория Пачкова,

Валентина Герасимова

\section{Менторинг формирования языковой личности в национально-региональных условиях Татарстана}

Авторы рассказывают о своем опыте поликультурного образования в гимназии №3 Зеленодольского муниципального района Республики Татарстан, введении менторинга при изучении английского, русского и татарского языков. Особая роль в воспитательном процессе отводится сотрудничеству с Ассамблеей народов Татарстана и созданному в гимназии музею «Известные татары современности» (ныне - Центр развития и популяризации татарского языка).

Ключевые слова: менторинг, интерференция, поликультурная гимназия, татарский язык, национальное образование, межкультурная коммуникация, транспозиция, Ассамблея народов Татарстана

Халитова Лейсан Хамитовна, заместитель директора по национальному образова нию, МБОУ «Гимназия №3 Зеленодольского муниципального района Республики Татарстан» (Зеленодольск), leisan_ham@mail.ru

\section{Пачкова Виктория Андреевна,} учитель русского языка и литературы, МБоУ «Гимназия №3 Зеленодольского муниципального района Республики Татарстан» (Зеленодольск)

\section{Герасимова Валентина}

Валериановна, учитель английского языка, МБОУ «Гимназия №3 Зеленодольского муниципального района Республики Татарстан» (Зеленодольск)
Менторинг как методическое явление хорошо развит на Западе и связан с особой ролью педагога-ментора, педагога-наставника, тьютора или консультанта. Формирование языковой личности как личности, реализованной в родном языке и национальной культуре, осложнено проблемами интерференции (последствиями влияния одного языка на другой). Устойчивая интерференция, когда семантическая база родного языка плохо взаимодействует с семантической базой второго или третьего языка, провоцирует развитие смешанного билингвизма, что, в свою очередь, затрудняет развитие когнитивных функций, отрицательно влияет на интеллект, мышление, речепорождение, на культуру речевого поведения как на первом, так и на втором и третьем языках.

Наша гимназия - поликультурное образовательное учреждение, здесь учатся дети разных национальностей: русские, татары, узбеки, чуваши, марийцы, украинцы, лезгины, азербайджанцы. Как в любой многонациональной школе, нам особенно важно сформировать у наших учеников уважение, дружелюбие и доверие к окружающим, независимо от их национальности, к их культуре, языку, традициям. Язык обучения - русский. Языковое образование в школе носит полилингвальный характер: кроме родного языка (русского), ведется преподавание английского языка, в качестве государственного и родного для ряда учащихся - татарский.

Целью формирования поликультурного пространства стало формирование высокого уровня коммуникативной компетентности как средства современной межкультурной коммуникации; развитие личности, способной к активной и эффективной жизнедеятельности в многонациональной и поликультурной среде, обладающей развитым чувством понимания и уважения собственной национальной культуры иных национальных культур.

Именно поэтому в гимназии №3 Зеленодольска Республики Татарстан менторинг играет особую роль: при обучении и русскому, и татарскому, и английскому языкам, в паре с учителями работают опытные наставникименторы, которые помогают и коллегам, и школьникам успешно преодолевать языковую интерференцию. Конечно, остаются проблемы, связанные с отсутствием программ, учебников, дидактических материалов, построенных на учете явлений интерференции и транспозиции Такие материалы крайне необходимы для формирования продуктивной языковой личности в национальнорегиональных условиях России. Тем не менее педагоги- 
менторы (руководители методических объединений) совместно с учителями языковых дисциплин интегрируют языковое содержание по линиям транспозиции положительного переноса одинаковых языковых универсалий с родного языка на второй, со второго на третий. Например, если на родном (русском) языке рассматриваются имена существительные, то на втором (татарском) могут рассматриваться только существительные, на третьем (английском) имена существительные рассматриваются с опорой на первые два языка.

В результате таких методических операций складывается синхронизованная методическая система, позволяющая преодолевать интерференцию и развивать языковую личность, владеющую тремя языками. Например, традиционно в нашей гимназии празднуют День родного языка. Учащиеся представляют проекты и исследования, связанные с изучением языков (например, групповые проекты по русскому языку о влиянии смс-сленга на нашу речь или о необходимости беречь чистоту языка), читают стихотворения и прозу, поют песни на татарском языке. Дети других национальностей выступают на своих родных языках, выходя на сцену в национальных костюмах. И поскольку в гимназии дети изучают и английский язык, то учащиеся представляют мюзиклы на английском языке. Подобные праздники развивают кругозор и социальную активность детей, повышают мотивацию к изучению русского, татарского и английского языков, заинтересованности культурой других народов, представители которых живут рядом с нами и о которых, как оказывается, мы так мало знаем.

В 2010 г. на базе гимназии был создан музей «Известные татары современности». Он посвящен нашим современникам - талантливым представителям татар- ского народа, которые благодаря таланту, трудолюбию и целеустремленности добились успеха, стали для наших ребят примером для подражания. Их яркие победы, персональные достижения побуждают учащихся, независимо от этнической принадлежности, ставить перед собой цели, добиваться их, стремиться вперед. Экскурсии ведутся на трех языках: татарском, русском и английском, что позволяет учащимся на практике применить знания, полученные на уроках, развивать коммуникативные способности на трех языках. В 2017 г. в связи с отменой обязательного изучения предмета «Татарский язык и литература» музей стал Центром развития и популяризации татарского языка.

На базе музея функционирует клуб интересных встреч «Аралашу», на заседания клуба мы приглашаем знаменитых представителей татарского народа, ветеранов, известных и успешных людей. Гимназисты встречались с поэтами, актерами, писателями, художниками, спортсменами. Среди них заслуженный артист Российской Федерации Георгией Ибушев, заслуженный артист Республики Татарстан Риф Карамутдинов, наш выпускник ученый-химик Айрат Димиев, поэтесса Эльмира Шарифуллина, член Союза художников России Диля Барышева, заместитель редактора газеты «Ватаным Татарстан» Фания Ахметзянова, чемпионка мира по пауэрлифтингу Айгуль Ситдикова.

Музей активно сотрудничает с городскими и республиканскими СМИ, Советом ветеранов города, общественной организацией «Ак калфак», местным отделением Исполкома Всемирного конгресса татар. Заседания клуба проводятся на русском и татарском языках. Подобные встречи в отличие, например, от запланированных и заранее составленных экскурсий позволяют детям в процессе живого общения применить знания, 
полученные на уроках татарского и русского языка, позволяют говорить, общаться на другом языке, понимать чужую речь.

Для интеллектуального и творческого развития, приобщения учащихся к исследовательской, поисковой деятельности, активизации научно-практического творчества и поддержки талантливых учеников с 2014 г. на базе музея: гимназии «Известные татары современности» проводится межрегиональная научно-практическая конференция «Татары, прославившие свой народ». Рабочие языки конференции - русский и татарский. Руководят проектами детей не только учителя татарского или русского языка, но и педагоги-предметники. Особенно важно взаимодействие учителей русского и татарского языка. Учителя-наставники, руководители школьных методических объединений, согласуют направления работы, темы, учителя татарского языка и литературы консультируют учителей русского языка, акцентируя внимание на специфике татарской литературы того или иного периода, обозначая круг тем и мотивов, свойственных тому или иному писателю, поэту, уточняя художественные особенности произведений. Такое взаимодействие обогащает опыт учителей, позволяет выбрать то направление в работе, которое будет интересно и понятно ребенку.

Сегодня молодое поколение остро нуждается в социальных ориентирах, опирающихся на национальные ценности в русле общечеловеческой направленности. Построение воспитательного процесса на традициях этнической культуры придает ему гуманистический характер, способствует формированию ценностных ориентаций, духовно-нравственной устойчивости, гражданско-патриотической позиции, этнической идентичности. Поддержание этнокультурных традиций пробуждает у воспитанников генетическую память, обеспечивает преемственность поколений, способствует значительному повышению результативности воспитательного процесса.

22 июня 2012 г. представительство Ассамблеи народов Татарстана предложило нашей школе вступить в актив этой республиканской общественной организации. Деятельность Ассамблеи направлена на стабилизацию общественно-политической ситуации в республике путем удовлетворения этнокультурных, этносоциальных потребностей, а также участия в решении этнополитических проблем многонационального народа Татарстана; на повышение и поддержание на высоком уровне рейтинга, авторитета, престижа Татарстана, как зоны межнационального и межконфессионального мира, спокойствия и развития.

Детское объединение «Молодежное крыло» в нашей гимназии было создано в ноябре 2012 г. Ребята проводят разные мероприятия не только в стенах родной школы, но и сотрудничают с другими подобными молодежными объединениями в родном городе и за его пределами, принимают участие в творческих конкурсах.

Әтнокультурное воспитание предполагает использование различных форм работы: уроки, классные часы, мастер-классы, факультативы, кружковые занятия, конкурсы, праздники, ярмарки, игры, походы, экскурсии, экспедиции. Каждый отдельный урок, каждое отдельное внеклассное мероприятие должны отражать культурную жизнь и органически входить в систему воспитательной работы. В гимназии стали традиционными такие формы работы с семьями, как выпуск семейных рефератов (к которым ежегодно добавляется новая страничка), проектная деятельность, ведение семейных фотоальбомов, изготовление совместных поделок, приготовление национальных блюд, фотовыставки и фоторепортажи, семейные праздники, фольклорные 
развлечения с участием родителей. Все это сплачивает семьи, способствует доброжелательным отношениям всех участников образовательного процесса.

Фоторепортажи помогают больше узнать о семьях, о их традициях, национальном укладе, поделиться своими успехами, рассказать о предках, знаменитых родственниках. Одно из любимых мероприятий в гимназии - это «Полотно дружбы» с конкурсом пословиц, на праздник съехались гости - казанские студенты разных вузов. Запомнился вечер «Воспевшие журавлей...», на котором гимназисты узнали, кто такой Расул Гамзатов, Марк Бернес, Наум Гребнев, Ян Френкель, Муслим Магомаев, а также японская девочка из Хиросимы Садако Сасаки. А потом дети научили гостей делать бумажных журавликов.

В начале учебного года мы выпускаем стенд «Ассамблея народов Татарстана». Руководитель молодежного крыла и учитель английского Валентина Валериановна Герасимова помогает разрабатывать рубрики, а дети наполняют его содержанием. Этот стенд используются в течение года в работе с детьми по темам «Семья», «Моя родословная», «Мой город», «Семья за здоровый образ жизни», «Наши друзья», «Праздничный календарь». Последний раздел, например, рассказывает о том, какие государственные, национальные и семейные праздники отмечаются в семьях, в городе или республике, например татарский «Сабантуй», азербайджанский «Науруз», марийский «Пеледыш пайрем».

Этническая культура способствует формированию гармоничной целостной личности. Наивысшим показателем уровня развития этнокультуры молодых людей является их готовность и способность к этнокультурной трансляции, благодаря чему сохраняется устойчивость самого этноса и обеспечивается преемственность и эффективность воспитания.

\section{Leysan Khalitova}

Deputy Director for national education,

Gymnasium No. 3 of the Zelenodolsk municipal district

of the Republic of Tatarstan (Zelenodolsk), leisan_ham@mail.ru

\section{Victoria Pachkova}

Teacher of Russian language and literature, Gymnasium No. 3

of Zelenodolsk municipal district of the Republic of Tatarstan (Zelenodolsk)

\section{Valentina Gerasimova}

English teacher, Gymnasium No. 3 of Zelenodolsk municipal district of the Republic of Tatarstan (Zelenodolsk)

\section{Mentoring of language personality formation in national and regional conditions of Tatarstan}

The authors tell about their experience of multicultural education in Gymnasium No. 3 of Zelenodolsk municipal district of the Republic of Tatarstan. They introduce the mentoring in the study of English, Russian and Tatar languages. A special role in the educational process is given to cooperation with the Assembly of peoples of Tatarstan and the gymnasium Museum «Famous Tatars of our time» (now the Center for the development and popularization of the Tatar language)

Keywords: mentoring, interference, multicultural gymnasium, Tatar language, national education, intercultural communication, transposition, Assembly of the peoples of Tatarstan 